\title{
Moment JouRnAL
}

Journal of Cultural Studies, Faculty of Communication, Hacettepe University 2019, 6(2): 447-469

ISSN: 2148-970X.

Articles (Theme)

\section{DICHOTOMY BETWEEN WAR AND VISUALIZATION OF WAR: AN ANALYSIS OF THE WAR PHOTOS AWARDED BY THE WPP}

\author{
Onur Dursun* \\ Filiz Yıldız \\ Serkan Bulut ${ }^{* * *}$
}

\section{Abstract}

Wars, having negative effects on local, national and global scales, violate the fundamental rights of living beings and, in general, cause irreversible casualties. War is a phenomenon that affects life itself and the entire social structure and institutions. Although death, physical injury, or psychological consequences are well known to war, their macro-level damage to the social structure is often overlooked. The mass media also tend to focus on the obvious consequences of the war while ignoring its structural impact on society.

This research applies content analysis to the images of the war theme awarded in various categories by the World Press Photo Organization, towards inquiring to what extent possible impacts and

\footnotetext{
* Associate Professor., Çukurova University Communication Faculty, Department of Journalism. ORCID ID: 0000-0001-9268-0936, odursun@cu.edu.tr, dursunonur@gmail.com.

** Associate Professor, Çukurova University Communication Faculty, Department of Journalism. ORCID ID: 0000-0002-1206-4314, filizyildiz@cu.edu.tr, yildizfiliz2000@yahoo.com

${ }_{* * *}$ Doctoral researcher, Çukurova University Communication Faculty, Department of Journalism. ORCID ID: 0000-0001-8252-5262, serkanbulut@cu.edu.tr, serkanblt88@gmail.com Date of Submission: 17/07/2019 Date of Acceptance: 05/12/2019

(c) Author(s) (or their employer(s)) 2019. Re-use permitted under (CC BY-NC 4.0.) No commercial re-use. See open access policy. Published by Faculty of Communication, Hacettepe University.
} 
consequences of wars are represented via such images. The study concludes that usually Western photojournalists create war narrative while the geography of conflict depicted is mostly non-Western. It also concluded that the war was visualized by themes such as death, injury and disability, displacement, hunger, and deprivation, that the moments of war are highlighted while its long-term implications are ignored; that war is portrayed without subjects by symbolic images, often indirect; and that war is viewed as a hierarchical field in terms of the perpetrator and the victim.

\section{Key Terms}

photojournalism, World Press Photo, visualisation of war, Western gaze, war photography

\section{SAVAŞ VE GÖRSELLEŞEN SAVAŞ ARASINDAKI IKILEM: WPP'NIN ÖDÜLLENDIRDIĞi SAVAŞ FOTOĞRAFLARI ÜZERINE BIR ANALIZ}

Öz

Savaş, yerel, ulusal ve küresel düzlemlerde güçlü olumsuz etkileri olan, canlıların temel haklarını ihlal eden ve çoğunlukla da geri dönüşü olmayan felaketlere yol açan bir durumdur. Savaş, etkilerini toplumsal yapının bütün yaşam alanlarında ve kurumlarında hissettiren bir olgudur. Savaş, ölüm, yaralanma, bedensel ve ruhsal etkiler bırakma gibi etkileriyle bilinen ama çoğu kez toplumsal yapı üzerindeki makro ölçekli hasarlarının ihmal edildiği bir çatışma sürecidir. Medya da sunumları ile savaşa ilişkin bu genel bakış açısını, yani ölüm ve yaralanma gibi durumları öne çıarma ve toplum üzerindeki makro etkileri/sonuçları da ihmal etme eğilimindedir. Bu çalışma, Dünya Basın Fotoğrafı Vakfı (World Press Photo Organisation [WPP]) tarafından çeşitli kategorilerde ödüllendirilen savaş temalı fotoğraflara içerik analizi uygulayarak, savaşların olası etkilerini ve sonuçlarını bu görseller aracıllı̆ıyla ne ölçüde temsil ettiğini araştırmayı amaçlamıştır. Analiz, uluslararası alanda savaş anlatısının çoğunlukla Batılı foto-muhabirleri tarafından inşa edildiğini, savaşın coğrafyası olarak ise Batılı olmayan bölgelerin gösterildiği sonucuna varmıştır. Ayrıca foto-muhabirlerinin savaşı görselleştirirken ağırlıklı olarak ölüm, yaralanma ve engellilik, yer değiştirme, açlık ve yoksulluk gibi temalar üzerinden kurduğu; savaş esnasına odaklanarak uzun erimli sonuçları genel olarak ihmal ettikleri; savaşı öznesiz göstererek anlatımı büyük ölçüde dolaylı-sembolik imgeler üzerinden kurdukları sonuçlarına ulaşılmıştır.

\section{Anahtar Terimler}

foto muhabirliği, Dünya Basın Fotoğrafı Vakfı, savaşın görselleştirilmesi, Batılı bakış, savaş fotoğrafçılı̆̆ı 


\section{Introduction}

Ever existing wars have been a prominent force throughout all historical periods in shaping the history of humanity through inhuman acts. Downfall of empires/states or foundation of new ones, significant changes in the socio-cultural or economic structures, for better or worse, have been among numerous consequenses of the war.

The etymology of the word "war" stems from Old High German "werra" which means conflict, disturbance, disaccord or dispute. Similarly, the expression of "war" is used as a meta term throughout this study, encompassing its different forms, such as "civil war" and "domestic disturbance". According to van der Dennen (1995, p. 69), war is a form of violence and specifically, is a collective, direct, open, personal, intentional, organized, institutional, instrumental, imposed and sometimes ritualized and coordinated violence. Each side applies physical force to their opponents in order to force them to comply with their specific wishes - "our will" - and tries to render "the enemy" incapable.

With the technological developments merged into the process, wars increasingly have not only become systematical and ended with mass destruction, but they also have been transformed into new dimensions (Townshend, 2000; van Creveld, 2000). Currently, conflicting states or actors of wars might use different mechanisms beyond physical power to establish hegemony over their opponents. The concepts of cyber warfare and proxy war are the upmost examples of these new scales of war. The power struggle taking place on economic grounds, the so-called "trade war" between the USA and China is just a recent example; one of the fronts being Google, a USA company recently cancelling the software updates for the cellphones of a Chinese firm, called HUAWEI.

War is certainly a process and has diverse impacts on people and societies (Roseman, 2000). Stein and Bruce (1980, p. 400-401) explain under the topic of "timing of impact" that while some consequences of war are instant, the others may emerge long after its cessation. Coşkun suggests that violence is incorporated into war in two ways. The first one is the direct violence, which is, explicit or implicit, application of force or power to a given group, or people. amounting to corporal or physical violence. The other one is the implicit-indirect or structural violence and shows itself as poverty, exploitation, discrimination and social injustice, antidemocratic discourse and practices (Coşkun, 2018). This impact can be classified as a postwar impact or consequence. Kant 
(2015) extends the consequence of war by carrying it further from the level of human death to the level of society. War does not only kill people but also darkens the future of a society/country by bringing completely negative living conditions. Scharre (2018) argues that despite so much American blood spilled, so many billions of dollars spent and national honor damaged, no problem was solved during the wars since 1945.

Mass media has a significant impact on people's understanding of the World around them and plays a great role in constructing the public opinion regarding wars, their causes and consequences (Luhmann $(1993,775)$. As the basic providers of information and content across continents, media organizations may even set the agenda, particularly powerful at national or international level, not only for their own countries but also for the world. (Tuchman, 1978; Hallin, 1986; Chomsky, 1989; Gans, 2003; Schudson, 2010; Firmstone, 2012).

People learn from or obtain media-based views without having any knowledge of the specific conflict itself (Somerville, 2017; Manor \& Crilley, 2018). For example, along with the arguments that US media shaped the public's perception and attitude towards the US invasion of Iraq, a poll by The Washington Post found out that $69 \%$ of the US population believed that Saddam Hussein was responsible for the 9/11 attack (İnceoğlu, 1997, p. 86-87). The Iraq war, according to Schechter (2003, p. 15-27) was also normalized among the people through the media portraying war as a justified intervention. In the same vein, the accusations against countries such as the United States and the United Kingdom of using the media to fight terrorism in line with their national interests appeared in related literature (Mughan \& Gunther, 2000; Bek, 2010).

The arguments that a distorted version of reality is presented by mass media and news as its commodity is not only proposed and widely emphasized by the critical theory but it is also articulated from time to time by the liberal pluralist theory (Poyraz, 2002). Östgaard (1965) argues that in the international communication system the newsworthiness requirements within the progressive model misrepresent and bias international news. The manipulation of international news, according to Östgaard, creates assumptions of negative quality for other nations thus preventing good relations and stability. While Kepplinger and Weissbecker (1991) link some of the criteria of newsworthiness, such as negativity, to ideology, arguing that developed countries tend to emphasize negative news about less developed and developing countries.

Examining the role of photographs in creating memories, Annette Kuhn conclude that even though photographs carry legibility as a kind of proof, they do not 
mirror reality or carry a value of the seen; and that despite what is commonly argued, photographs cannot be directly linked to what they show. In this respect, according to Kuhn, as tools of commentary, photos are a sort of evidence to be examined and decoded like a riddle or clues on a crime scene (cited by Griffin, 1999, p. 147).

Following from the widely articulated concern in the related literature about the practices of manipulation by the mass media via the power of photos, and hence based on the need for closer analyses of images, this study sets out to explore how war is visualized and presented through photos. More specifically, the study aims to uncover which dimensions of the war are reflected through war photography, by examining 161 images awarded by the WPP with themes of war. The first part of the paper focuses on historical and theoretical aspects and visualization styles of photojournalism. The research design and categories of analyses are covered in detail in the next section, followed by the presentation of the findings and the discussions on the findings.

\section{Photojournalism and visualization of war}

Photojournalism is an influential field which helps to generate collective memory by offering visual sequences about a fact or a situation. The fact that it creates a sense of reality and is perceived as a kind of document is an important factor of its effectiveness. Although the main product of print media is the text itself, photography has become an indispensable adjunt adding new dimensions by enforcing the text's meaning and credibility. Particularly in the news conveying big scale events to society, news photos are seen as documents of proof for gaining the trust of the audience, as well as attracting their attention. Photography was perceived as the transmitter of reality since the very beginning. This perspective, fed by the positivist thought of the 19th century, has regarded the camera as a tool of obtaining objective and tangible data. Arguments in this line, suggested that a camera lens would present the view of the physical world more effectively than the human eye. To specify, Roland Barthes regards visualization to be more essential than the text, as images display the meaning without diluting it or without the need of an analysis (cited by Hall, 1973), and Harold Evans (1980) posits that important world events such as a war can only be comprehended through visual documents since they create a sense of certainty.

The roots of photojournalistic objectivity lean on the notion that photojournalists do not affect their subject matter to the degree that they are almost considered to be invisible while recording/documenting (Cartier-Bresson, 1952; Perlmutter, 1995; Busst, 
2012). On the other hand, idealization of photography as 'objective representation of reality' would soon be challenged. Berger states that shooting is a conscious act of choosing; and the act of making a choice gives the photographer a responsibility (1972, p. 8). That is, the photographer is as much responsible for what not to display as what to choose, and what to display. As Susan Sontag $(1977$, p. 90) quotes from Minor White, "the state of mind of a photographer while creating is blank...when looking for pictures.... The photographer projects himself into everything he sees, identifying himself with everything to know it and to feel it better."

Photos convince people by showing them what they cannot see through personal experience and facilitate understanding. Since people tend to believe what they see more easily, the image on the photo has a visual impact. Thus, photos are a particular way of slowly establishing dominant points of view. They suppress their ideological dimensions by presenting themselves as exact recordings of the visual world. News photos, almost, carry a meta-message such as "This actually happened and this photo is the proof" while bearing witness to the event represented. As Barthes put it, all photos are a way of saying "I was there" (Hall, 1973). However, the weakness of the photography lies in the fact that it is instantaneous. In other words, it can only record the very instance of shooting and it fails to convey what happened before or after the captured event. As emphasized by John Berger (1980, 1982) and Susan Sontag (1977), a photo only freezes time while moments before and after it disappear into the ether (cited by Andersen, 1989; Yıldız, 2012).

An important part of the field of photojournalism is war photography. The beginning of first-hand documentation of war by journalists' is the Crimean War that took place between 1853 and 1856. First war photos were taken by Roger Fenton who was sent to Crimea on behalf of the United Kingdom in 1855. William Howard Russell, who had stayed in Crimea for 22 months and told of what had been happening to the English public through The Times, is acknowledged as the first war correspondent in the modern sense (Saul, 1968; Griffin, 1991, Høiby \& Ottosen, 2019). Since the 19th century, recording wars through photos and their use in newspapers have become widespread. Photos, as much as the news itself, have always been used to sway the public opinion on the war, two new technologies, the rail system and the telegraph, were significant for the rise of modern war correspondence. The Crimean War was a period when newspapers, as the mass communication medium, and news reporting practices gained strength and momentum. And then, during the American Civil War, the press gained 
strength, and war correspondents almost became mythical heroes (Therenty \& Pillet, 2012; Risso, 2017).

Over time, war correspondence became an area of expertise thanks to the development of communication technologies and transport. For example, photojournalists created impactful images of war during the Second World War. Margaret Bourke-White, a war photographer, proudly recited that she caught a visual composition which is totally detached from subjectivity; through distancing herself from her feelings and using all the appropriate photographic techniques when filming a family who died during the Second World War in a German airstrike (Goldberg, 1986). As speedy transmittance of photos and news to newspapers ensured prestige to war correspondences in the 1940s, newspaper readers were able to picture the war in their minds through photos available to them (Mathews, 1957).

After the Second World War, the use of visual data in the war news became even more popular. The Korean War was the first war to be televised, while the news about the Vietnam War was presented in detail through graphs and charts to accompany photos. Historically, the Gulf War in 1991 was the first 24-hour live broadcast war. The reporting of the Iraq War in 2003 included the creation of war images via internet technology, and suitable live videos, photos, audios, animations and interactive maps (Harmon, 2003, p. 4).

Since the beginning of the 20th century, war photos have brought fame to many photographers. Such tabloidized images have shaped the perception of people on wars. The best example might be the rising anti-war sentiments during the Vietnam War. War correspondents are usually stuck between the pressures of journalistic integrity and management of media, the state, the army, and the public. Some war correspondents describe themselves as independent, objective and critical, while others who report the first and second US-Iraq wars were accused of becoming soldiers of the state and the army. In this context, some major media organizations have lost the trust of their audiences and have been accused of serious ethical violations for not criticizing actions of the government. As some critics have pointed out, the Pentagon's embedded journalism system, which first emerged as a way to manage strategic media during the Iraq War, called into question the integrity of journalism in the US media (LeBlanc, 2013; Høiby \& Ottosen, 2019).

Kellner (2008, p. 299) also argued that during the Gulf War in 1991, the Afghanistan War in 2001 and the Iraq War in 2003, newspapers, radio and television 
broadcasting enforced the messages of the army and the state whereas critical approaches were rare. For example, flight of tens of thousands of Kurds to the mountains from the persecution of Saddam Hussein, or causing the deaths of hundreds of thousands of people as well as exposing 27 million people to famine during civil wars in Africa were not seen as newsworthy by the media (Moeller, 2002).

\section{Objective and methodology}

This study aims to explore the way in which possible dimensions, effects and consequences are reflected in the photos awarded by WPP with the theme of war. In this study, quantitative content analysis was applied and photos were categorized and examined. The samples examined in the study consists of WPP's prize categories. The foundation has awarded more than thousand photos in 42 categories from 1955 to 2018. The WPP was chosen for sampling because it is an established and professional evaluation organization in the field of photojournalism, and it has the power to comprehensively represent international photo-journalism. As an organization, the WPP evaluates around one hundred thousand photos each year and awards those that are found successful. In other words, the WPP is a pillar which conclusively approves photos' success. Moreover, another important reason for the choice of the WPP for sampling is that it is both a Western organization and that $71,14 \%(\mathrm{n}=444)$ of its jurors are from different Western countries (from Europe, North America, and Australia).

The WPP generally awards the first, second and third prize to photos under the categories of "Singles" or "Stories", apart from such categories as Photo of the Year. The WPP awards only one photo in the Singles while awarding more than one photo (telling a story) in the Stories. To reach better results from the quantitative analysis and to prevent misleading results, this study only examined "Singles" sub-categories of WPP's non-thematic categories. In other words, all thematic categories and the categories awarding only under the "Stories" were excluded from the sample of the study. Hereby a total of 611 photos were depicted from 19 main categories between 1955 and 2018. The inquired categories are as follows: Budapest Award, Citation for Creativity, Color Picture, Contemporary Issues, Daily Life, General Features, General Picture, Features, General News, Miscellaneous, News, News Features, Novosti / TASS Prize, Organized News, Public's Favorite, People, People in the News, Photo of the Year, Spot News. However, 7 of the 611 photos included in the study are not available as image in WPP's contest collection (which are News 3rd in 1956 and 3rd in 1966; General Features 2nd in 
1969; Color Picture 3rd in 1966, 3rd in 1967, 3rd in 1968, 3rd in 1969). Thus, only 604 photos are used for analysis. But, since Photo of the Year is selected within all categories, the winner of Photo of the Year might also be the winner of another category -for example, the first prize of Spot New category was also Photo of the Year. In such cases, only the photograph in the main category was taken into account and the same photograph in Photo of the Year category was excluded. This was the case with 28 out of the 60 photos in Photo of the Year. For this reason, just 32 photos were included in the study specific to this category. Moreover, when a photograph was awarded both in Budapest Award and in General News, it was examined only in Budapest Award. Again, since a photograph was awarded both in Features and in Public's Favorite, it was only examined in Features. After all, 574 photos under 19 categories were scrutinized in the study. It was determined that 161 out of 574 photos had the theme of "war". The study elaborates on the dimensions of the concept of war identified as visualized by photojournalists in these 161 photos.

Various categories of analysis were generated for the study (Rose, 2016, p. 54-68). Firstly, the geographical regions where the photo awarded by WPP ${ }^{1}$ were taken and the citizenship of the photographers shooting them were identified. Secondly, the 161 war photos were independently examined by three researchers to obtain the categories of analysis. Accordingly, 14 categories, highlighted through the photos regarding possible impacts of war were identified, also in accordance with the related literature. The themes presented below, are interrelated by being causes or consequences of each other.

Death: Death is the worst and the most feared outcome of the war since it has an irreversible, permanent and instantaneous impact. Deaths sometimes even come upon masses. However, people do not die only during wars. Negative living conditions and various severe epidemics in and during the war regions may indirectly cause high number of deaths (Iraq Family Health Survey Study Group, 2008; Tapp at al, 2008; Crawford, 2013; Jones, 2013; Guha-Sapir, at al, 2018). According to Levy and Sidel's (2007, p. 4-5) data, approximately 121 million deaths were directly or indirectly caused by wars over the 20th century.

Injury/Wound and Disability: A large number of people are injured/wounded or become disabled because of firearms, bombs, chemical weapons, explosions and other

\footnotetext{
1 World Press Photo's committee, of whom the producers of the photos and the juror have common background, is composed of investigators on photography and media professionals of photojournalism, thus the rewarding process embraces professional photography codes of the vocation.
} 
causes. Certain cases of injuries and being disabled come about during war while the other cases are observed in the following periods, and are even passed down to future generations. For example, the atomic bomb dropped on Japan, chemical Agent Orange used in Vietnam, sarin gas used in Syria caused people to become disabled or be born with a disability. Such cases can be multiplied.

Displacement: Due to security concerns during wars, people often flee their homes to survive, and cross legally or illegally international borders into other nations as refugees/asylum-seekers, or find safety somewhere in other regions within their countries as IDPs (Internally Displaced Persons). For various reasons (illness, famine, etc.), absconding groups can be taken into refugee/detention camps by the governments of target countries. The concept of refugee/asylum-seeker may be encountered as a typical-general consequence of war in the Middle East, Asia, and Africa. For example, the Turkish Grand National Assembly data dated March 2018 suggests that there are more than 2 million 750 thousand Syrians in Turkey as refugees/asylum-seekers, of whom 250 thousand are located in various refugee camps (TBMM Göç ve Uyum Raporu, 2018).

Economic Problems: War can damage the country's financial resources and result in the loss of infrastructure, loss of working population, rise in debt, disruption of production capacity and decrease in GDP. The economic crisis caused by war lies in the foundation of the impacts compiled below. In Marxist terms, all mobility in the substructure also defines the superstructure. Depending upon the economy, unemployment will rise, production processes will be damaged, health and education services will be interrupted, and cultural-daily life etc. will be influenced negatively (Collier, 1999; Nordhaus, 2002; Baker, 2007; Kecmanovic, 2013; Costalli, at al, 2014; Institute for Economics \& Peace, 2018).

Famine-Poverty: During war, one of the main distresses that exist alongside economic problems is famine and poverty. At the same time being detrimental countries' economic structure, Asia, Central and Latin America, and particularly Africa exemplify this situation well. Colonization of these regions by the invasion of European countries, consummating their political and financial unity, lead to people live on the brink of the hunger.

Disease and Health System: Among the devastations brought upon by war are serious, contagious and fatal diseases. For example, poor living conditions such as insufficient nutrition and inadequate health services have caused diseases such as 
cholera, dysentery, hepatitis, and many deaths in the Middle East and Africa. Furthermore, war-related psychological issues are among the factors that have a negative impact on human health (Ugalde, at al, 1999). Moreover, destruction and harm, closing, or blockading the use of health services and buildings also cause people to lose their lives or to maintain unhealthy lives (see also Levy \& Sidel, 2007; Teerawichitchainan \& Korinek, 2012).

Educational Problems: Institutions can also be damaged during the war. Destruction of educational institutions or interruption of education as a result of disruption of everyday life is one of the main negative impacts of war. In a case such as war people cannot complete their educations (Kecmanovic, 2013).

Governmental Problems: The negative conditions created by wars cause organizations such as governments or bureaucracies to break down or completely change, or bring harm to people working within these organizations. The impact of war on government can sometimes result in more democratic systems while other times can transition into anti-democratic systems. For example, Shah's Revolution in Iran was a transition from a modern government into a sharia. In Chile's Military Coup of 1973, the democratically chosen adminstration was taken down.

Destruction of Daily Living Spaces: Unquestionably, daily living spaces are among the areas in the war zone that can be damaged. Houses, workplaces, public life spaces (park, garden, street, avenue, etc.) are amongst the spaces likely to be harmed in war. To harm life spaces means to harm people directly.

Destruction of Environment/Nature: Firearms or chemical weapons used in the wars destroy nature, and have a detrimental impact on future generations as well as killing and crippling people directly. For example, atomic bombs dropped on Hiroshima and Nagasaki ruined the natural system and the flora of both cities. The chemical named Agent Orange deployed by the US in Vietnam can also be included in this category.

During all the phases mentioned above with the regard to war, mass media, while performing its primary, formal function of accurately disseminating news to the public plays on important role in many aspects.

Additionally, three headings, namely, Showdown, Captivation, and Tabloidization were added to the categories of analysis, as it was noted that some photos focused on a showdown, some visualized people being captivated and some covered war in a tabloidizing way. Thereafter, three aspects of the impacts and 
consequences that the narrative of war was construed upon were considered. Namely, it was observed whether they were (1) direct or indirect on a symbolic level, (2) instantaneous or long term, (3) persistent or ephemeral. Finally, it was questioned whether the photos portrayed the war through the perpetrators or the victims. Accordingly, the analyses followed this order with respect to those who are shot in the photos and those who shoot the photos (in the dichotomy of Western and nonWestern), Themes by which wars were conveyed, Impacts and Consequences, and Perpetrators and Victims of the war narratives.

\section{Findings}

The disaccord between those who shoot the photographs and who are shot

Following the widely accepted view that each photo is a reflection of point of view of the photographer and that there are diverse elements which determine the frame; cultural visions, experiences of the photographer are regarded as primary factors guiding their choices in building the frame (Lutz and Collins, 1991). In this section, findings related to the geographical regions of the wars and the citizenships of photographers in the data are first presented, considering geographies as primary cursors of cultures. As illustrated in Table 1, in detail, of the total 161 award-winning photos, $65,84 \%$ were identified to be taken in Asia, 16,77\% in Africa, 11,80\% in Europe, $3,11 \%$ in South America, and 2,48\% in Central America.

When evaluating the data based on countries, Palestine and Vietnam take the first place in terms of frequency with 17 photos each. These countries are followed by Iraq with 16 photos, Afghanistan with 13, Syria with 12, Russia with 7, Lebanon with 6, and Bosnia-Herzegovina with 5. As the findings (Table-1) suggest, long grueling wars in the Middle East ${ }^{2}$ were visualized via award-winning photos. In total, there are 8 countries with more than 5 war photos and 5 out of these 8 countries are located in Middle East.

\begin{tabular}{|l|l|l|l|l|l|l|l|l|l|l|l|}
\hline Country & $\mathbf{n}$ & $\%$ & Country & $\mathbf{n}$ & $\%$ & Country & $\mathbf{n}$ & $\%$ & Country & $\mathbf{n}$ & $\%$ \\
\hline
\end{tabular}

\footnotetext{
${ }^{2}$ There is no consensus on which countries are Middle Eastern countries. Studies show these countries differently. Our study considers Bassam Tibi's approach to Middle Eastern countries. Accordingly, Middle Eastern countries are: Egypt, Turkey, Iraq, Bahrein, Algeria, Tunisia, Israel, Cyprus, Iran, Qatar, Morocco, Mauritania, Syria, Sudan, S. Arabia, the UAE, Libya, Jordan, N. Yemen, Kuwait, Oman, Lebanon, S. Yemen (Tibi, 1989, p. 76).
} 


\begin{tabular}{|l|l|l|l|l|l|l|l|l|l|l|l|}
\hline Palestine & 17 & 10,56 & Albania & 3 & 1,86 & Austria & 1 & 0,62 & Libya & 1 & 0,62 \\
\hline Vietnam & 17 & 10,56 & Angola & 3 & 1,86 & Burundi & 1 & 0,62 & Nicaragua & 1 & 0,62 \\
\hline Iraq & 16 & 9,94 & Kosovo & 3 & 1,86 & Colombia & 1 & 0,62 & North Korea & 1 & 0,62 \\
\hline Afghanistan & 13 & 8,07 & Somalia & 3 & 1,86 & Croatia & 1 & 0,62 & Pakistan & 1 & 0,62 \\
\hline Syria & 12 & 7,45 & UK & 3 & 1,86 & Cuba & 1 & 0,62 & Peru & 1 & 0,62 \\
\hline Russia & 7 & 4,35 & Zaire & 3 & 1,86 & Cyprus & 1 & 0,62 & Romania & 1 & 0,62 \\
\hline Lebanon & 6 & 3,73 & Chad & 2 & 1,24 & Congo, DR & 1 & 0,62 & Saudi Arabia & 1 & 0,62 \\
\hline $\begin{array}{l}\text { Bosnia- } \\
\text { Herzegovina }\end{array}$ & 5 & 3,11 & Chile & 2 & 1,24 & Egypt & 1 & 0,62 & Sierra Leone & 1 & 0,62 \\
\hline Cambodia & 4 & 2,48 & India & 2 & 1,24 & El Salvador & 1 & 0,62 & South Africa & 1 & 0,62 \\
\hline Myanmar & 4 & 2,48 & Iran & 2 & 1,24 & Germany & 1 & 0,62 & Ukraine & 1 & 0,62 \\
\hline Sudan & 4 & 2,48 & Liberia & 2 & 1,24 & Haiti & 1 & 0,62 & Venezuela & 1 & 0,62 \\
\hline Rwanda & 3 & 1,86 & Algeria & 1 & 0,62 & Kenya & 1 & 0,62 & Zimbabwe & 1 & 0,62 \\
\hline
\end{tabular}

Figure 1: War by countries

The second group of findings is about the citizenship of the photographers who have captured the photos. Firstly, they are categorized as external or internal observers based on their citizenships. The findings reveal that the photographers are mostly Western (from Europe, North America, and Australia). 65 of the photographers are from North America (63 from the USA, 2 from Canada), 62 from Europe, 22 from Asia, 5 from South America, 4 from Africa, 2 from Australia, and 1 from Central America. These results demonstrate that the wars generally take place in non-Western geographies $(88,20 \%)$, yet, those who visualize these wars are Westerners to a great extent $(80,12 \%)$.

As the findings in this category reveal, it is specifically noteworthy that even though $38,50 \%$ of the photojournalists who shoot the wars are from the USA, no awardwinning photo of war from the USA was detected. Two reasons maybe underlying this observation. One is that the USA had no wars directly in their own territory, although during the US intervention to Vietnam, to the Gulf, and Afghanistan and the Iraq wars, the US was practically a side of the wars. Another explanation might lie in the comments of LeBlanc (2013) and Høiby \& Ottosen (2019) who complain about the US strategic media management system claiming that the US brings its journalists to war by embedding them in its army.

Habermas (2001, p. 135) defines life-world as an object domain of social sciences, stating that social scientists' mission is to focus on objects, the "object domain of social 
sciences contains everything defined as a component of life-world". According to Habermas, it is not enough, for a social scientist, only to observe to attain the knowledge of mentioned objects, or to theorize about society, but it is also necessary to experience it by the way not different than a way of a common man. In order to understand the structures of life-world, the social scientist needs to be in the process of production of the structures (Habermas, 2001, p. 136). This view of Habermas may be extended through the concept of internal and external observer in this study. Both positions may have advantages and disadvantages for researching and interpreting the current situation. The external observer may approach events more objectively although s/he may be out of the socio-cultural context of the situation. On the other hand, while the internal observer, as a shareholder of the culture may absorb the situation more easily. Furthermore, the external observer, being a stranger to the target culture is more likely to otherize the people and the situations observed than the internal observer is.

The enquiry in this regard concluded that $88,82 \%(\mathrm{n}=143)$ of the photographers were external observers, while $11,18 \%(n=18)$ were internal observers. These results imply that most photographers, shooting the photos, are unfamiliar with the cultures and that they approach the countries where they take the photos as outsiders. In other words, the cultural geography of wars are different from the cultural geographies of the photographers. This means that those who shoot have the gaze of an outsider.

When it comes to media professionals, it may be assumed the correspondents producing media coverages about a familiar culture would be better equipped for approaching events/situations more realistically; whereas out-of-culture correspondents are more likely to lean on their general opinions in perceiving situations in other cultures.

As suggested by the findings of the study, a great majority of the photojournalists within the scope of our data can be regarded as external observers; it may be deduced that there is obvious cultural gap between the war photos examined 'objects' and photographers as 'subjects' (in Habermas's terms). Thus, the implication is that the East, geographical area of wars is visualized and documented, to a large extent, through the perspectives of the West. As Said (1997, p. 3-34) argues, there is a neverending war on the agenda of the world; in other words, there is an "anti-modern/antidemocratic East" which is considered as a threat to the "modern-democratic Western" countries, and it should, therefore, be intervened. So as to remind us the phrase attributed to 14th-century philosopher Ibn Khalduna, geography is fate. 
Clark (2000, p. 35-36) emphasizes that actors, holding power and owning wealth, as if confirming Voltaire's idea of "history is the lie commonly agreed upon", fictionalize conditions and developments around the world and combine these with the power of media under their control. Chomsky (1989, p. 269) also underlines that history engineering is as old as the history itself, and that the US has undertaken this mission with a professional responsibility since it intervened in the World War I.

\section{Visualization of war through death and injury/wounded}

In this section of the study, themes used in the construction of the war narrative through photography are investigated based on the general categories of analysis established as a result of independent observations of 161 photos, by three researchers.

Additionally, multi-encoding technique was used during the process; i.e.; a photo could be encoded in more than one category ${ }^{3}$. The 161 photos were thus encoded 219 times and the percentages were calculated out of the number 219.

As seen in Figure 1, death, injury/wounded, displacement and famine/poverty appeared to be the most prominent themes; to specify, death $(20,55 \%)$ had the highest frequency among others. Moreover, it was detected that the themes of Injury/Wound and Disability (15,98\%), Displacement (Refuge/Migration etc.) (14,61\%), Famine/Poverty $(10,50)$ were above $10 \%$. These findings suggest that the most apparent impacts and consequences of war such as death, injury/wounded, famine, poverty, displacement were focused on while narrating war through photos. Besides, the most dramatic aspects of the situation are brought to the fore and this is coherent with mainstream media's approach to news and reporting practices. Lastly, according to the ratios that were obtained, it can be contended that war photos do not represent all important effects of war on society while photos which narrate war through tabloidized images were also encountered. Some of the photos, evaluated within this scope and qualified as tabloidization/simplification of war, show "soldier in boxers", "soldier kissing his girlfriend", "soldiers doing karaoke" and "soldiers sunbathing on the terrace".

\footnotetext{
${ }^{3}$ For example, a photo of deceased person, most probably died due to poverty/famine caused by war, put into categories both poverty/famine and also death.
} 




Figure 2: Distribution of War Photos by Themes

\section{A symbolic war narrative}

Photos evaluated within the scope of the study were analyzed in two main categories of direct or indirect narrative based on their ways of describing the war. For example, the photo of a dead body captured in a hospital morgue is evaluated as an indirect/symbolic narrative, while the death scenes captured in moments of conflict/explosion etc. were marked as a direct narration. These findings suggest that $75,28 \%$ of the analyzed photos have visualized war symbolically. In other words, the shots were not taken in any specific moment/place of the war but afterwards, and $24,22 \%$ directly displayed images occurred in the actual instances and places of the war in progress. In this respect the results posit that the majority of the photographers do not visualize war directly but offer symbolic representations. This might be caused by photographers' fear for their lives as interpreted by Høiby\&Ottosen (2019). However, it wouldn't be unfair to say that this way of visualization of war cannot offer a deep understanding of what war is all about.

\section{The storytelling focus on the moment of war}

Even though destructions of war are instantaneous, their effects last for years and can be transferred onto future generations. War can impact society as a whole by firstly damaging the economy, and concordantly, established systems (Modell \& Haggerty, 1991; Bezabih, 2014). With this reasoning in mind, it was questioned whether the impacts/consequences depicted are the ones that occur during or after the war. The analysis in this context suggests that $88,20 \%(n=142)$ of the photos were taken during the time of war; while $11,80 \%(n=19)$ focused on impacts/consequences after the war. This result means that photographers prefer to visualize the impacts of war momentarily, 
and do not focus on post war processes. Yet, it is a known fact that injuries and deaths, economic problems, post war inadequacies in shelter, nutrition, health and education services, illnesses stemming from these conditions, technological incapacity, destroyed life and natural spaces, etc. negatively impact a large number of people, even cause deaths (see Ferguson, 2006).

Another categorization in this study is of the persistence or ephemerality of the impacts/consequences of war. Death, injury, disability and social/national/ethnic etc. extinction are among permanent impacts/consequences of war that will persist, while other impacts/consequences are taken as temporary, ephemeral impacts/consequences of war (Stein and Bruce, 1980). Across all samples, 50,31\% $(n=81)$ of the photos focus on persistent impacts while $46,69 \%(n=40)$ focus on the ephemeral. However, almost half of the elements constructing the war narrative include direct corporal impact on humans such as death, injury or disability. Therefore, it wouldn't unjust to say that war is mostly dramatized by media through the physical human body and its general impacts and consequences are ignored to a great extent.

\section{War narration without agency}

Sample photos were also investigated in terms of agencies involved in the images. In this regard photos are grouped as agents and victims. It was found out that 54 photos include men, 18 include children, and 12 include women as victims. 12 photos include women and children, 8 photos include men and children together as victims. 19 of the remaining photos visualize women, men and children together as victims, 1 shows an animal as victim. 24 photos don't contain or have any humans or living beings. When the data is calculated for only woman, only man and only child (for example $\mathrm{M}+\mathrm{MW}+\mathrm{MC}+\mathrm{A})$, it is found that men are in the first place with the total number of 93 , children occupy the second place with 59 , and women third by 56 .

When evaluated in terms of agency, it was observed that 50 photos contained agents of whom 49 are men and 1 is a boy. Agents were not detected in the remaining 111 photos. These results in a broad sense suggest that war is visualized through victims.

The study demonstrates that photographers identify the event of war fundementally with men. They are predominantly emphasized both as perpetrators and victims of war in photos. On the other hand, victimized women and children are underestimated. Moreover, 137 photos include victims while only 50 include agents. 
This can lead to the commentary that photos construct their war narrative through victims, and for the most part, hide agents. Another finding which supports this idea is the ratio $(26,09 \%)$ of offensive weapons (rocks, knives, guns, rifles, tanks, warplanes, etc.). Only 42 out of the 161 photos contain offensive weapon. These findings can be interpreted as a sign that war photos tend to construe war without agency (only $31 \%$ include agents).

\section{Conclusion}

Photography has become an indispensable component of mass media, with its capacity to capture the moment, and its power of narration through visualization, its dramatic impact on shaping the opinions, beliefs and attitudes of people on any issue and has been of serious concern to social scientists and scholars from different fields. Especially when considering the accelerating speed in the developments of technical possibilities in photography which bring about endless choices of vision to the photographer, it is emphasized in this study that the investigation of the area deserves closer scholarly attention.

Based on the close examination of award-winning war themed photos by the WPP, findings of this research are characterized to a large extent by the East-West dichotomy. To specify, the results of the quantitative analyses of the photos suggest that photojournalist who have taken the photos are mostly from the Western world while the majority of wars occur in the Eastern geographies. In this respect, it is implied that in most cases photojournalist shooting the photos in question, are external observers visualizing events from the international arena through their own cultural lenses. Findings of the study also suggest that the underlying messages of the war photos support the assumption that war is experienced predominantly outside of the Western geographies, and that wars are acts specific to the Eastern regions of the world.

Another instance of East-West dichotomy is also reflected in the war narrative constructed via photography where the narrative is created basically through the images of those who are victimized whereas neither agents nor their aggression are featured in the captured photos. This may also be interpreted as a way of distancing westerners from the scenes and responsibilities of war, at the same time addressing the Eastern world, emphasizing the motto 'war is theirs, not ours'.

It is also observed that post-war and long term impacts of wars are generally neglected; instead, dramatic dimensions of wars and their impact on physical human 
bodies and on other visible forms are foregrounded. In other words, war narratives are constructed and symbolized in the pivot of a limited number of themes; namely death, injury/disability, illness, immigration, refugees etc., underestimating the fact that war creates a general destruction on the society as a whole. Additionally, war photos are presented in a specific context (death, injury, violence etc.) which could also happen in daily life in diverse ways - rather than in a context which conveys the impression of a big scale event within the war. As similar practices of downgrading the importance of the impacts of wars, immediate physical consequences of war via moment-to-moment photography are carried to the forefront, and what happens right after the war is focused on, instead of the state of war in current war zones.

Finally, these findings concerning the way the realities of war are manipulated through the photos creating war narratives, might also be regarded as an evidence (and a hope) for the capability of media to change the situations for the better. Put shortly, the decision of a photographer when shooting a vision is indeed a matter of ethical choice.

\section{References}

Andersen, R. (1989). Images of War: Photojournalism, Ideology, and Central America. Latin American Perspectives, 16(2), 96-114.

Baker, D. (2007). The economic impact of the Iraq war and higher military spending. Centre for Economic and Policy Research, May 2007.

Berger, J. (1977). Ways of Seeing. London: BBC and Penguin Books.

Bezabih, W. F. (2014). Fundamental consequences of the Ethio-Eritrean war [19982000]. Journal of Conflictology, 5(2).

Busst, N. (2012). Telling Stories to a Different Beat: Photojournalism as a "Way of Life", Doctoral Thesis, Bond University, Australia.

Cartier-Bresson, H. (1952). The Decisive Moment, New York: Simon and Schuster.

Chomsky, N. (1989). Necessary illusions: Thought control in democratic societies. Pluto Press. UK.

Collier, P. (1999). On the economic consequences of civil war. Oxford economic papers, $51(1), 168-183$. 
Costalli, S., Moretti, L., \& Pischedda, C. (2017). The economic costs of civil war: Synthetic counterfactual evidence and the effects of ethnic fractionalization. Journal of Peace Research, 54(1), 80-98.

Crawford, N. (2013). Accountability for Killing: Moral Responsibility for Collateral Damage in America's Post-9/11 Wars. Oxford University Press.

Evans, H. (1980). Eyewitness:25 Years through World Press Photos. New York: William Morrow.

Ferguson, N. (2006). The war of the world: Twentieth-century conflict and the descent of the West. New York: Penguin.

Firmstone, J. (2012). European Media: structures, politics and identity. Journalism Practice, 6(3), 424-426. doi:10.1080/17512786.2011.650879.

Gans, H. J. (2003). Democracy and the news. New York: Oxford University Press.

Gencel Bek, M. (2010). Karşılaştırmalı Perspektiften Türkiye'de Medya Sistemi. Mülkiye, Vol. XXXIV. Issue 269. 101-125.

Goldberg, V. (1986). Margaret Bourke-White: A Biography, New York: Harper and Row.

Griffin, M. (1991). Defining visual communication for a multi-media world. The Journalism Educator, 46(1), 9-15.

Griffin, M. (1999). The great war photographs: Constructing myths of history and photojournalism. Picturing the past: Media, history, and photography, (Ed) Bonnie Brennen \& Hanno Hardt, University of Illinois Press.122-157.

Guha-Sapir, D., Schlüter, B., Rodriguez-Llanes, J. M., Lillywhite, L., \& Hicks, M. H. R. (2018). Patterns of civilian and child deaths due to war-related violence in Syria: a comparative analysis from the Violation Documentation Center Dataset, 201116. The Lancet Global Health, 6(1), 103-110.

Hall, S. (1973). The determinations of news photographs. The Manufacture of News: Social Problems, Deviance and the Mass Media, Sage. 176-190.

Hallin, D. C. (1986). The "Uncensored war": The media and Vietnam. New York: Oxford University Press.

Harmon, A. (2003). Improved tools turn journalists into a quick strike force. New York Times, 1.

Høiby, M., \& Ottosen, R. (2019). Journalism under pressure in conflict zones: A study of journalists and editors in seven countries. Media, War \& Conflict, 12(1), 69-86.

Institute for Economics \& Peace. 2018. The Economic Value of Peace 2018: Measuring the Global Economic (Linked: 
http://visionofhumanity.org/app/uploads/2018/11/Economic-Value-of-Peace2018.pdf).

Iraq Family Health Survey Study Group. (2008). Violence-related mortality in Iraq from 2002 to 2006. New England Journal of Medicine, 358(5), 484-493.

İnceoğlu, Y. (1997). Uluslararası Medya. Der Yayınları, İstanbul.

Jones, D. A. (Ed.). (2013). Genocide, war crimes and the West: history and complicity. Zed Books Ltd..

Kant, I. (2015). On Perpetual Peace. Broadview Press.

Kecmanovic, M. (2013). The short-run effects of the Croatian war on education, employment, and earnings. Journal of Conflict Resolution, 57(6), 991-1010.

Kellner, D. (2008). War correspondents, the military, and propaganda: Some critical reflections. International Journal of Communication, 2 (34), 297-330.

Kepplinger, H. M., \& Weißbecker, H. (1991). Negativität als Nachrichtenideologie. Publizistik, 36(3), 330-342.

LeBlanc, A. (2013). Embedded Journalism and American Media Coverage of Civilian Casualties in Iraq (Master's thesis, Universiteteti Tromsø).

Levy, B. S., \& Sidel, V. W. (Eds.). (2007). War and public health. Oxford University Press.

Luhmann, N. (1992). What is communication? Communication theory, 2(3), 251-259.

Lutz, C., \& Collins, J. (1991). The photograph as an intersection of gazes: The example of National Geographic. Visual Anthropology Review, 7(1), 134-149.

Manor, I., \& Crilley, R. (2018). Visually framing the Gaza War of 2014: The Israel

Ministry of Foreign Affairs on Twitter. Media, War \& Conflict, 11(4), 369-391.

Mathews, J.J. (1957). Reporting the Wars, Minneapolis: University of Minnesota Press,

Modell, J., \& Haggerty, T. (1991). The social impact of war. Annual Review of Sociology, 17(1), 205-224.

Moeller, S. D. (2002). Compassion fatigue: How the media sell disease, famine, war and death, Routledge.

Mughan, A., \& Gunther, R. (2000). The media in democratic and nondemocratic regimes: A multilevel perspective. In R. Gunther \& A. Mughan (Eds.). Democracy and the media: A comparative perspective (pp. 1-27). Cambridge University Press.

Nordhaus, W. D. (2002). The economic consequences of a war in Iraq (No. w9361). National Bureau of Economic Research.

Östgaard, E. (1965). Factors influencing the flow of news. Journal of Peace Research, 2(1), 39-63. 
Perlmutter, D. D (1995). Opening up Photojournalism, News Photographer, 50 (4), 9-11. Poyraz, B. (2002). Haber ve haber programlarında ideoloji ve gerçeklik. Ankara: Ütopya Publishing.

Risso, L. (2017). Reporting from the front: First-hand experiences, dilemmas and open questions. Media, War \& Conflict, 10(1), 59-68.

Rose, G. (2016). Visual methodologies: An introduction to researching with visual materials. Sage.

Roseman, M. (2000). "War and the People the Social Impact of Total War" (p. 281-301). The Oxford history of modern war (Ed. Charles Townshend). New York: Oxford University Press.

Saul, N. (1968). William Howard Russell, Russell's Despatches from the Crimea 1854-1856, (Ed.) Bentley Nicolas, New York: Hill and Wang.

Scharre, P. (2018). Army of none: Autonomous weapons and the future of war. WW Norton \& Company.

Schechter, D. (2003). Embedded: Weapons of mass deception: How the media failed to cover the war on Iraq. New York: Prometheus Books.

Schudson, M. (2010). Autonomy from what? In R. Benson \& E. Neveu (Eds.). Bourdieu and the journalistic field (pp. 49-63). Cambridge: Polity.

Somerville, K. (2017). Framing conflict-the Cold War and after: Reflections from an old hack. Media, War \& Conflict, 10(1), 48-58.

Sontag, S. (1977). On Photography. New York: Farrar, Straus \& Giroux.

Stein, A. A., \& Russett, B. M. (1980). Evaluating war: Outcomes and consequences. Handbook of political conflict: theory and research, 399-422.

Tapp, C., Burkle, F. M., Wilson, K., Takaro, T., Guyatt, G. H., Amad, H., \& Mills, E. J. (2008). Iraq War mortality estimates: a systematic review. Conflict and health, 2(1), 1 .

TBMM Göç ve Uyum Raporu. (2018) (Linked:

https://www.tbmm.gov.tr/komisyon/insanhaklari/docs/2018/goc_ve_uyum_rapo ru.pdf)

Teerawichitchainan, B., \& Korinek, K. (2012). The long-term impact of war on health and wellbeing in Northern Vietnam: Some glimpses from a recent survey. Social science \& medicine, 74(12), 1995-2004.

Therenty, M-E and Pillet, E .(2012). Presse, chanson et culture au XIXe siècle: La parole vive au défi de l'ère médiatique. Paris: Nouveau Monde. 
Tibi, B. (1989). Konfliktregion Naher Osten. Regionale Eigendynamik.

Townshend, C. (2000). "Introduction: The Shape of Modern War" (3-19). The Oxford history of modern war (Ed. Charles Townshend). New York: Oxford University Press.

Tuchman, G. (1978). Making news: A study in the construction of reality. London: Collier MacMillian Publication.

Ugalde, A., Richards, P., \& Zwi, A. (1999). Health consequences of war and political violence. Encyclopedia of violence, peace and conflict, 2, 103-121.

van Creveld, M. (2000). "Technology and War I: to 1945" (p. 201-223). The Oxford history of modern war (Ed. Charles Townshend). New York: Oxford University Press.

van der Dennen, J. M. G. (1995). The origin of war: The evolution of a male-coalitional reproductive strategy, Vols. 1 \& 2. Origin Press.

von Clausewitz, C. 1984. On War. Edited and translated by Michael Eliot Howard and Peter Paret. Princeton University Press, Princeton: New Jersey.

Yıldız, İ. (2012). 20. Yüzyılda tanıklık olarak savaş fotoğrafları ve resim ilişkisi üzerine bir inceleme, VI. International Young Art Historians Symposium, 27-29 November 2012, Turkey. 